\title{
Ocean science and policy
}

\author{
Societal commitment to protect our seas has never been higher, but it will not succeed unless coordination across \\ the various regulatory bodies involved is achieved.
}

( ver the past few decades, technological progress has made deeper and wider explorations of the oceans possible, and as a result our understanding of oceans and their function has advanced significantly. Yet, a lot remains unknown. In 2017, UNESCO and the Intergovernmental Oceanographic Commission released the Global Ocean Science Report (https:// go.nature.com/2xwN2E2). Researchers from all over the world assessed for the first time the status and trends in ocean science capacity globally in light of the Sustainable Development Goals (SDGs) agenda, and in particular the challenges of meeting SDG 14 about sustainable management of the oceans. The report offers an opportunity to many across academia and policy domains to identify knowledge and capacity gaps and understand how to strengthen the sciencepolicy interface around the oceans.

With better knowledge has come increased alarm about the impacts of uncontrolled human activities on marine and coastal environments. Beyond mere academic discourse, a number of initiatives have worked intensively to raise societal awareness about the importance of protecting the oceans for sustainable development. One example is the Sustainable Ocean Initiative that aims at catalysing partnerships and action to achieve the Aichi Biodiversity Targets in marine and coastal areas (www.cbd.int/soi). Another example is World Ocean Day, which has been celebrated on the 8th of June every year since 2002 to help increase public engagement with ocean conservation efforts (www.worldoceansday.org). Many more initiatives are under way, often seeing academia and civil society joining up efforts to inform and potentially influence policy decisions.

Indeed, policy decisions should be informed by the latest scientific evidence, but they nevertheless face some constraints as the livelihoods of many communities worldwide depend on the use of marine and coastal resources. Increasing demands on natural resources combined with better technologies have led to an increased level of commercial exploitation of the oceans. In a brief released on 6 April 2018 (http:// go.nature.com/2gF95vh), the World Bank Group emphasized the adoption of the so-called Blue Economy - an approach to promote economic growth while ensuring the environmental sustainability of oceans and coastal areas. In the brief, we learn that the World Bank's active Blue Economy portfolio is worth US\$3.7 billion. The World Bank finances sustainable fisheries and aquaculture (around US\$1.1 billion), conservation of coastal and ocean habitats (US $\$ 1.5$ billion) and coastal infrastructure such as waste treatment, watershed management and other activities that are fundamental to reduce coastal and marine pollution (around US\$1.1 billion).

But ocean-based sustainable development plans should also look at the environmental implications of non-living resources extraction - a source of income to many economies that come with significant environmental impacts. Oil, gas and minerals mining is under way near the coast in many countries, and much has been learned about the potential risks of these activities. However, technological developments have made deep-sea extraction activities a reality, though our knowledge of deep-sea habitats is still fairly limited, and so any assessment of the associated environmental risks remains challenging.

And ultimately with extraction as well as fishing activities, water jurisdiction and maritime legislation take centre stage. Ocean governance is a complicated and multilayered framework involving stakeholders and institutions from local to national and international levels. The most significant achievement in legislating ocean usage and sovereignty at international level is represented by the United Nations Convention on the Law of the Sea that was signed in 1982 - a sort of constitution of the oceans. It addresses issues like, for example, freedom of navigation rights, territorial sea boundaries and exclusive economic zones up to 200 miles offshore (https://go.nature.com/2J1cWFc). However, the zoning system set out by the Convention is in conflict with the goal of an overall sustainable governance of the oceans. For example, in the exclusive economic zone a coastal state alone has the right to exploit marine resources, whereas the high seas are open to all countries with some restrictions. Also, fish stock and toxic pollutants do not stay within the boundaries of economic zones. In addition, different institutions handle different aspects of the ocean. Just simply looking at the UN level, the International Maritime Organization lays down the rules for international commercial shipping, whereas the International Seabed Authority administers exclusively the mineral resources in high seas. Many other bodies are involved in various other aspects of the oceans, and at different levels, and a high number of agreements are in place so that coordination to achieve sustainable management of the oceans is far from easy.

Finally, any legislation has to be respected in practice. There is a need for adequate monitoring and enforcement mechanisms. Some progress has been made; for instance, a country's port authorities can detain a ship found in breach of international regulations. Disputes between countries however are much harder to resolve - a violation of marine borders can lead to a sentence by the International Tribunal for the Law of the Sea, but the country sentenced might not accept the judgement. In such cases the last resort is diplomacy, a rather weak solution (https://go.nature.com/2suD40S). Overall, there is a significant range of interests focused on the oceans, and governance rules and institutions are fragmented. Our hope is that awareness of the need to keep the oceans healthy for the benefit of current and future generations will pull all interested groups together in a joint effort to protect our precious seas.

Published online: 14 June 2018 https://doi.org/10.1038/s41893-018-0091-3 